\title{
Saurida golanii, a new deep water lizardfish (Pisces: Synodontidae) from the Gulf of Aqaba, northern Red Sea
}

\author{
BARRY C RUSSELL \\ Museum and Art Gallery of the Northern Territory, PO Box 251 Darwin, NT 0810, Australia. E-mail: barry.russell@nt.gov.au
}

\begin{abstract}
Saurida golanii sp.nov. is described on the basis of eight specimens collected from bottom-set trammel nets in deep water (200-500 m) off Eilat, in the Gulf of Aqaba, northern Red Sea. The new species is characterised by the following combination of characters: lateral-line scales 53-56; transverse scale rows $4 \frac{1}{2} / 51 / 2$; long pectoral fins (extending beyond a line from origin of pelvic fins to origin of dorsal fin); caudal peduncle compressed (depth greater than width); and pelvic fins unpigmented.
\end{abstract}

Key words: taxonomy, Pisces, Saurida golanii, Gulf of Aqaba, Red Sea

\section{Introduction}

The lizardfish (family Synodontidae) genus Saurida comprises about 20 species found in tropical and subtropical seas. They commonly occur on continental shelfs associated with soft muddy or sandy bottoms in depths usually to about $200 \mathrm{~m}$, although some species are associated with shallow reef areas. Four species are reported from the Atlantic (Anderson et al. 1966), with the remainder occurring in the Indo-West Pacific (Russell 1999). A single species, recorded from the Mediterranean is a Red Sea - Suez Canal migrant (Golani 1993).

The most recent checklist of Fishes of the Red Sea (Golani \& Bogorodsky 2010) lists three species of Saurida: S. gracilis (Quoy \& Gaimard 1824); S. macrolepis Tanaka, 1917 (formerly recorded as Saurida undosquamis - see Inoue \& Nakabo 2006; Golani \& Bogorodsky 2010); and S. tumbil (Bloch 1795).

Deep water fishing off Eilat, Israel, in the Gulf of Aqaba, northern Red Sea, using bottom-set trammel nets in depths of 200-500 m, has yielded an additional new species. This species, previously reported by Baranes and Golani (1993) as Saurida tumbil, is distinct from that species and is described herein as new.

\section{Material and methods}

Methods of counting and measuring follows Shindo and Yamada (1972) and Inoue and Nakabo (2001), except that all length measurements are from the anterior-most tip of the snout, including the upper lip. In addition, teeth rows on the tongue were counted as the number of teeth across the width of the posterior part of the tongue. Measurements were taken with digital calipers to the nearest $0.1 \mathrm{~mm}$. Vertebral counts were taken from radiographs.

Proportional measurements were calculated as the percentage of standard length (SL) or head length (HL) (Table 1). In the species description, counts and measurements for the holotype are given first, followed, where different, by the range (in parentheses) for the paratypes. Type-specimens are deposited in the collections at the Bernice P. Bishop Museum, Honolulu (BPBM); Zoological Museum, Hebrew University of Jerusalem (HUJ); Muséum national d'Histoire naturelle, Paris (MNHN); Museum and Art Gallery of the Northern Territory, Darwin (NTM); and Zoological Museum of Tel-Aviv University (TAU). 


\section{Saurida golanii sp. nov.}

Proposed name: Golani's lizardfish

(Fig. 1, Table 1)

Saurida tumbil (non Bloch). - Baranes and Golani, 1993: 303, Plate II, Fig. 9 (Gulf of Aqaba).

Holotype. HUJ 14018, 275.8 mm SL, Red Sea, Gulf of Aqaba, Eilat, Israel, off Heinz Steinitz Marine Biology Laboratory, 14 December 1989; three walled bottom monofilament trammel net, $300 \mathrm{~m}$ depth.

Paratypes (7 specimens). BPBM 31816, 280.8 mm SL, Red Sea, Gulf of Aqaba, Eilat, Israel, off Heinz Steinitz Marine Biology Laboratory, gill net. HUJ 11427, $325.1 \mathrm{~mm}$ SL, Red Sea, Gulf of Aqaba, off Eilat, Israel, 1983; three walled bottom monofilament trammel net, $330 \mathrm{~m}$ depth. HUJ 11947, $364 \mathrm{~mm}$ SL, Red Sea, Gulf of Aqaba, off Eilat, Israel, 1986; three walled bottom monofilament trammel net, $350 \mathrm{~m}$ depth. MNHN 2011-0230 (ex HUJ 11880), 281.5 mm SL, Red Sea, Gulf of Aqaba, off Eilat, Israel, 1 September 1986; three walled bottom monofilament trammel net, $500 \mathrm{~m}$ depth. NTM 17095-001, $360.6 \mathrm{~mm}$ SL, same data as preceding specimen. TAU P13778, 2: 213.6-223.0 mm SL, Red Sea, Gulf of Aqaba, off Eilat, Israel, 2930N, 34 ${ }^{\circ} 65 \mathrm{E}$; 11 March 2010, three walled bottom monofilament trammel net, $400 \mathrm{~m}$ depth.

Diagnosis. A species of Saurida with the following combination of characters: lateral-line scales 53-56; transverse scale rows $4 \frac{1}{2} / 5^{1 / 2}$; long pectoral fins (extending beyond a line from origin of pelvic fins to origin of dorsal fin); caudal peduncle compressed (depth greater than width); and pelvic fins unpigmented.

Description. Counts and proportional measurements of the type series are provided in Table 1.

Dorsal-fin rays 11 (11-12); pectoral-fin rays 15 (14-15); pelvic-fin rays 9; anal-fin rays 11 (10-11). Pored lateral-line scales 53 (53-54); transverse scale rows above lateral-line 41/2, transverse scale rows below lateral-line 51/2; scale rows below lateral line with melanophores 4; pre-dorsal scales 18 (17-18); pre-adipose scales 16 (1617); post-adipose scales 10 (10-11). Vertebrae $48-50$.

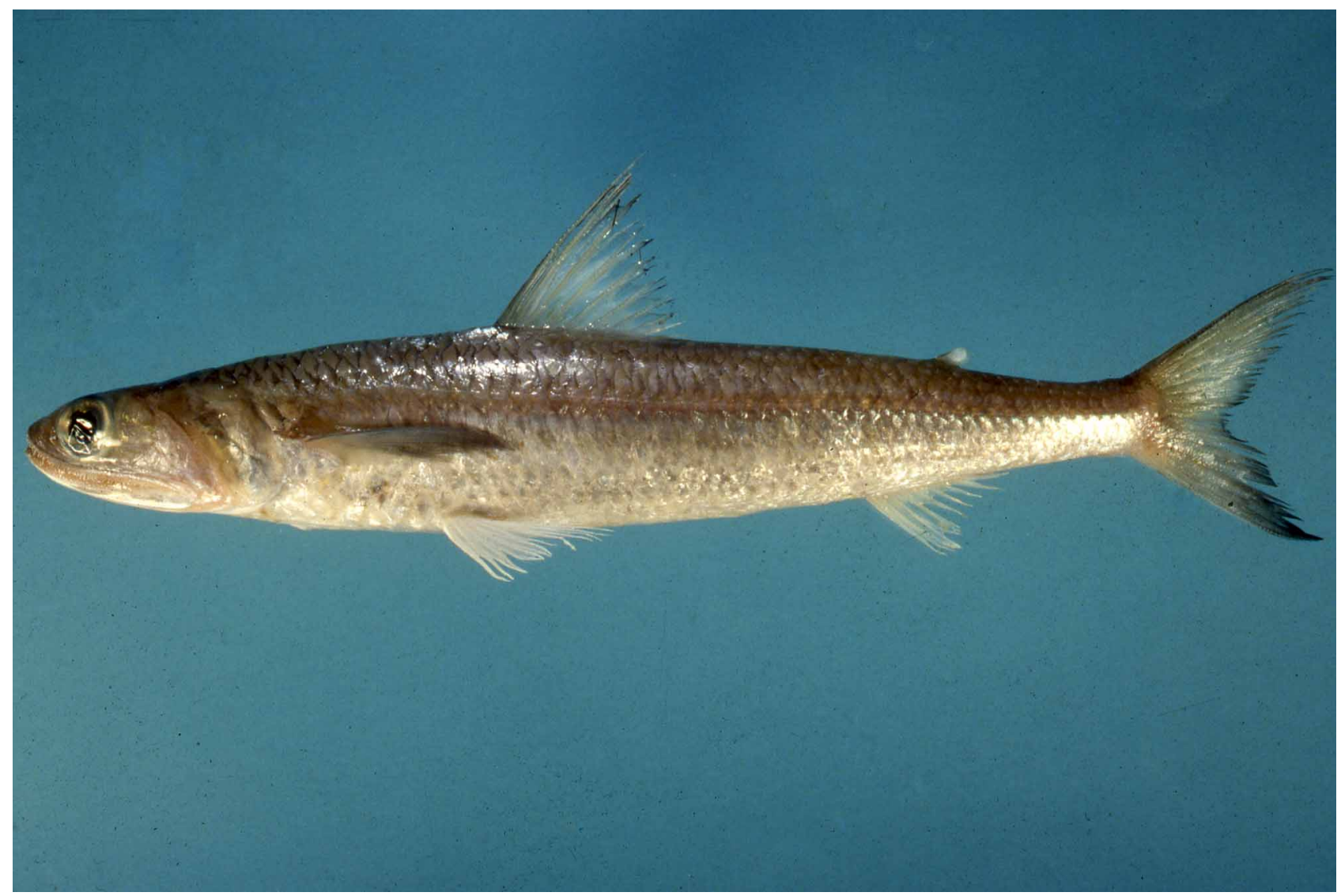

FIGURE 1. Saurida golanii sp.nov., holotype, 275.8 mm SL, HUJ 14018 (Photograph by David Darom). 
TABLE 1. Counts and proportional measurements of the holotype and seven paratype specimens of Saurida golanii sp. nov., expressed as percentages of standard length.

\begin{tabular}{|c|c|c|}
\hline & $\begin{array}{l}\text { Holotype } \\
\text { HUJ 14018, } 275.8 \mathrm{~mm} \mathrm{SL}\end{array}$ & $\begin{array}{l}\text { Paratypes } \\
7 \text { specimens: } 213.6-364 \mathrm{~mm} \mathrm{SL}\end{array}$ \\
\hline \multicolumn{3}{|l|}{ Counts } \\
\hline Dorsal fin & 11 & $11-12$ \\
\hline Pectoral fin & 15 & $14-15$ \\
\hline Pelvic fin & 9 & 9 \\
\hline Anal fin & 11 & $10-11$ \\
\hline Pored lateral-line scales & 53 & $53-54$ \\
\hline Transverse scales above lateral-line & $41 / 2$ & $41 / 2$ \\
\hline Transverse scales below lateral-line & $51 / 2$ & $51 / 2$ \\
\hline Scale rows below lateral line with melanophores & 4 & 4 \\
\hline Pre-dorsal scales & 18 & $17-18$ \\
\hline Pre-adipose scales & 16 & $16-17$ \\
\hline Post-adipose scales & 10 & $10-11$ \\
\hline No. vertebrae & - & $48-50^{*}$ \\
\hline No. rows of palatine teeth anteriorly & 3 & 3 \\
\hline No. of vomerine teeth & 1 & $0-1$ \\
\hline No. teeth rows across tongue & 4 & $4-6$ \\
\hline Proportional measurements & $\%$ of SL & $\%$ of SL \\
\hline Predorsal length & 42.5 & $38.4-43.3$ \\
\hline Preadipose length & 80.9 & $73.3-81.0$ \\
\hline Preanal length & 72.8 & $71.0-74.4$ \\
\hline Preanal fin length & 75.4 & $73.5-77.2$ \\
\hline Prepectoral length & 27.6 & $26.7-29.4$ \\
\hline Prepelvic length & 40.1 & $38.6-42.1$ \\
\hline Head length (HL) & 26.8 & $25.4-27.5$ \\
\hline Body depth & 15.8 & $11.0-14.0$ \\
\hline Body width & 15.2 & $13.3-15.1$ \\
\hline Interpelvic width & 10.1 & $7.3-9.7$ \\
\hline Pectoral fin length & 18.2 & $13.9-18.0$ \\
\hline Pelvic fin length & 16.7 & $14.0-16.2$ \\
\hline Length of $2^{\text {nd }}$ dorsal ray & 21.2 & $17.5-22.1$ \\
\hline Length of last dorsal ray & 5.5 & $4.2-6.5$ \\
\hline Length dorsal fin base & 13.6 & $12.0-13.8$ \\
\hline Length of $2^{\text {nd }}$ anal ray & 8.9 & $8.4-9.4$ \\
\hline Length of last anal ray & 4.6 & $4.4-5.2$ \\
\hline Length of anal fin base & 9.1 & $7.8-10.9$ \\
\hline Length of caudal peduncle & 14.6 & $13.3-15.7$ \\
\hline \multirow[t]{2}{*}{ Depth of caudal peduncle } & 6.8 & $5.9-6.8$ \\
\hline & $\% \mathrm{HL}$ & $\% \mathrm{HL}$ \\
\hline Snout length & 19.0 & $19.6-21.7$ \\
\hline Eye diameter & 24.9 & $19.9-25.4$ \\
\hline Snout width & 27.4 & $24.3-27.5$ \\
\hline Interorbital width & 18.0 & $16.1-21.6$ \\
\hline Post orbital length & 58.6 & $56.9-65.8$ \\
\hline Upper jaw length & 68.0 & $66.8-70.2$ \\
\hline
\end{tabular}

* Based on BPBM 31816 and HUJ 11947 
Body elongate and cylindrical, somewhat depressed on head and compressed on caudal peduncle, the latter with slight ridge on scales of the lateral line; scales large, cycloid, not very deciduous; scales present on cheek and opercle. Snout rounded when viewed from above. Nostrils located about midway between snout tip and anterior margin of orbit; anterior nostrils a little larger than posterior, anterior one with dermal flap posteriorly. Eye circular, directed laterally; covered with fleshy adipose eyelid anteriorly and posteriorly. Interorbital region concave.

Mouth very large, extending well beyond posterior margin of eye. Teeth on jaws numerous, small, canine-like, generally in four rows, outermost teeth smallest, innermost longest, visible when mouth closed; similar teeth on the palate, tongue and branchial arches; palatine teeth in two separate series: outer series long and in three rows, with anterior teeth longer, inner series short, in about five poorly defined rows; outer palatine series converge anteriorly but separated by vomer which is toothless or bears $1(0-1)$ tooth; tongue short, spatulate, with about 4 (4-6) rows of teeth; lower jaw slightly shorter and fits into groove between teeth at tip of upper jaw; gill rakers absent, branchial arches each with about 3 rows of teeth, those on the inside largest.

Origin of dorsal fin posterior to midpoint of distance from snout to adipose fin origin; base of dorsal fin longer than that of anal fin; adipose fin above sixth to eighth anal-fin rays; anus just anterior to origin of anal-fin; pectoral fin long, 18.2\% (13.9-18\%) in SL; tip of fin reaching well beyond a line from base of pelvic fin to origin of dorsal fin (P-D line); axillary scale of pectoral long and pointed, that of pelvic shorter; caudal fin deeply forked.

Peritoneum pale; stomach dark-pigmented anteriorly, intestine black.

Colour in alcohol. Brown on back, paler below lateral line, pigment extending to about four or five scale rows below lateral line; pectoral fins dusky over upper two thirds of fin; pelvic fins pale; dorsal, caudal and anal fins pale, anterior margin and posterior edge of dorsal and caudal fins dusky; adipose fin whitish, with dark anterior margin.

Colour of fresh specimens. Top of head and back dark brown, scales on back narrowly edged with black; paler brown below lateral line, extending down flanks; ventral surface silvery white; leading edge and outer margin of dorsal fin dusky; adipose fin whitish, its anterior margin dusky; upper edge and outer margin of caudal fin dusky, and lower lobe also dusky; upper two thirds of pectoral fin dusky; ventral and anal fins translucent.

Distribution. Saurida golanii sp. nov. is known only from the northern Red Sea (Gulf of Aqaba), where it is common in depths between 200 and $500 \mathrm{~m}$ (Baranes and Golani 1993).

Etymology. Named in honour of Dr Daniel Golani of the Zoology Museum, Hebrew University of Jerusalem, for his very significant contribution to Red Sea ichthyology. The name golanii is treated as a noun in the genitive case. The common name Golani's lizardfish is proposed for this species.

Comparison. This species was recorded by Baranes and Golani (1993) as Saurida tumbil, but differs from that species in a number of significant characters: the pectoral fins are longer (extending to well beyond P-D line, versus fin short, not reaching to P-D line in S. tumbil); caudal peduncle is compressed (depth greater than width, versus peduncle depressed, its width about equal to or slightly greater than depth in $S$. tumbil); and the pelvic fins are unpigmented (versus middle rays of pelvics dusky in S. tumbil).

Remarks. Saurida golanii sp. nov. has the deepest known distribution of any species of Saurida in the IndoWest Pacific. Its occurrence in depths of $200-500 \mathrm{~m}$ is similar to other more typically shallow water species in the Gulf of Aqaba that have also been captured in deep water (Baranes and Golani 1993). This phenomenon is probably a consequence of the unusual deep convective mixing of warmer surface waters to depths of $600 \mathrm{~m}$ or more, that occurs in the Gulf of Aqaba (Wolf-Vecht et al. 1992), resulting in an almost constant temperature throughout the water column (Reiss \& Hottinger, 1984) that extends the distribution of many species of shallow water origin into much deeper water (Baranes \& Golani 1993).

\section{Acknowledgements}

Thanks are due to Daniel Golani (HUJ), Menachem Goren (TAU) and John E Randall (BPBM) for loan of specimens and information. The photograph of the holotype was taken by Dr. David Darom. Rex Williams provided Xrays of the types. 


\section{References}

Anderson, W.W., Gehringer, J.W. \& Berry, F.H. (1966) Family Synodontidae. Memoirs of the Sears Foundation of Marine Research 1(5), 30-102.

Baldwin, C.C. \& Johnson, G.D. (1996) Interrelationships of Aulopiformes. In: Stiassny, M.L.J., Parenti, L.R. \& Johnson, G.D. (Eds) Interrelationships of fishes. Academic Press, San Diego, pp. 355-404.

Baranes, A. \& Golani, D. (1993) An annotated list of the deep-sea fishes collected in the northern Red Sea, Gulf of Aqaba. Israel Journal of Zoology, 39, 299-336.

Bloch, M.E. (1795) Naturgeschichte der ausländischen Fische. Vol. 9. J. Morino, Berlin, 192 pp.

Golani, D. (1993) The biology of the Red Sea migrant, Saurida undosquamis, in the Mediterranean and comparison with the indigenous confamilial Synodus saurus (Teleostei: Synodontidae). Hydrobiologia, 271, 109-117.

Golani, D. \& Bogorodsky, S.V. (2010) The Fishes of the Red Sea-Reappraisal and updated checklist. Zootaxa, 2463: 1-135.

Inoue, T. \& Nakabo, T. (2006) The Saurida undosquamis group (Aulopiformes: Synodontidae), with description of a new species from southern Japan. Ichthyological research, 53(4), 379-397.

Quoy, J.R.C. \& Gaimard, J.P. (1824) Description des Poissons. Chapter IX; In: Freycinet, L.de (Ed.) Voyage autour du Monde...exécuté sur les corvettes de L.M. "L'Uranie" et "La Physicienne", pendant les années 1817, 1818,1819 et 1820. Paris, pp. 1-328.

Reiss, Z. \& Hottinger, L. (1984) The Gulf of Aqaba. Ecological Micropaleontology. Ecological Studies. Vol. 50. Springer-Verlag, Berlin, $354 \mathrm{pp}$.

Russell B.C. (1999) Synodontidae. In: Carpenter, K.E. \& Niem, V.H. (Eds) The living marine resources of the Western Central Pacific. FAO species identification guide for fishery purposes, volume 3, part 1. FAO, Rome, pp 1928-1945.

Shindo, S. \& Yamada, U. (1972) Descriptions of three new species of the lizardfish genus Saurida, with a key to its IndoPacific species. Uo, 11, 1-13.

Tanaka, S. (1917) Six new species from Japanese waters (in Japanese). Zoological Magazine (Tokyo), 29(340), 37-40.

Wolf-Vecht, A., Paldor N. \& Brenner, S. (1992) Hydrographic indications of advection/convection effects in the Gulf of Elat. Deep-Sea Research Part A, 39, 1393-1401. 